\title{
Development of Biodiesel Plant Design Integrated with Palm Oil Mill for Diesel Fuel Substitution in Oil Palm Industry
}

\author{
Imam Paryanto ${ }^{a^{*}}$, Agus Kismantoa and Maharani Dewi S., Harianaa \\ ${ }^{a}$ Center for Engineering Design and Technology System - BPPT, Gedung 480 PUSPIPTEK Tangerang Selatan 15314 Banten, Indonesia
}

\begin{abstract}
One of the biodiesel production problems is the high price of plant oil as a raw material, causing the high cost of biodiesel in the market and less competitive compared to the diesel fossil fuel. Most biodiesel production plants which, are located far from the raw material source, especially from palm oil mill, and are not integrated with palm oil mill can cause the cost of raw material even higher, and hence increased biodiesel production cost. This problem needs to be anticipated and solved by integrating the biodiesel plant with the palm oil mill, so that some of the crude palm oil produced or off-grade palm oil recovered from POME can be processed and converted to biodiesel product. Biodiesel can further be used as diesel-substitute fuel for the operation of palm plantation and palm oil mill. With this integration concept, the investment and production costs can be less because of the availability of crude oil raw material and utilities (water, steam and electricity) in the palm oil mill.

To implement the idea of integration strategy to become reality, the development of engineering design of biodiesel plant integrated with palm oil mill is needed with the consideration of some technical aspects of : (i) the internal need of diesel fuel, (ii) supply of raw material, (iii) the selected production process, (iv) the availability of utilities and, (v) calculation of estimated investment and production costs. The concept of integration is the combined and merged business of biodiesel production and palm plantation and oil mill. This concept will give the optimum profit and benefit for utilization of crude palm oil or off-grade palm oil for producing biodiesel to substitute the consumption of diesel fuel in the palm industries.
\end{abstract}

Keywords: Biodiesel, Biodiesel Plant, Diesel Fuel Substitution, Integrated Biodiesel Plant, Palm Oil Mill

\section{Introduction}

Biodiesel has become a new alternative fuel for the future fuel demands because its abundant raw material sources, renewable and low environmental effects. Biodiesel fuel has similar properties to that of petrodiesel fuel, and can be used directly for existing diesel engines or as a mixture with petro-diesel fuel (Paryanto et al, 2013).

Biodiesel has been utilized for some time due to the impact of national energy policy (Government of Indonesia, 2006), although they are not used in all areas of Indonesia. One of the reason is that the price to produce biodiesel is sometimes not economical, especially because of the higher price of oil raw material and the higher fuel distribution cost to some rural areas. Therefore, the selection of oil raw material with low cost and availability of raw material in rural areas becomes an attractive issue in the biofuel production in Indonesia.

Major raw materials used to produce biodiesel are vegetable oil, alcohol (methanol) and catalyst. The selection of the oil feedstock is one of the important keys for the cost of sustainable biodiesel production. One of the potential oil feedstocks for biodiesel production in Indonesia is crude palm oil (CPO) and its derivatives, such as stearine (RBDPS) and palm fatty acid distillate (PFAD) (Paryanto et al, 2013).

Indonesia as the world's biggest producer of crude palm oil (CPO) has recorded the total CPO production of 25.5 million tones at the end of year 2012 (Investor Daily, 2012). The palm oil industries have given not only palm-based products and derivatives but also palm waste.

\footnotetext{
* Corresponding Author: Tel: +62-21-7563213/17

Email: imam.paryanto@bppt.go.id
} 
The most significant of waste from palm oil mill is palm oil mill effluent (POME). POME is voluminous waste which is organic in nature but has unpleasant odour and highly polluting. About 2.5 tons of this waste are produced for every ton of CPO extracted in palm oil mill. The concentration of oil and grease in POME is about $6,000 \mathrm{mg} / \mathrm{L}$ (Ahmad et al, 2008). The oil and grease in POME can be extracted and become an attractive raw material for production of biofuels, because they are low grade oil with high content of free fatty acid and impurities, but very low price.

Some biodiesel producers in Indonesia have stopped their production due to high oil raw material price and hence, the production cost. Although the biodiesel plant was integrated with palm oil mill, however, the oil raw material used was CPO and there was a transfer cost of CPO from palm oil mill to the biodiesel plant. To produce biodiesel from low grade palm oil extracted from POME requires appropriate technology so that biodiesel produced is at high conversion/yield and low in production cost (Paryanto et al, 2007). If CPO and offgrade CPO (collected from the waste pond) are used, therefore, the biodiesel plant has to be located and integrated in the area of palm oil mill so that it is more sustainable. In order to implement this strategy, a study was conducted to develop the engineering design of the biodiesel plant integrated with palm oil mill. Some technical aspects were considered such as the supplydemand of petro diesel fuel to be substituted with biodiesel, the need and selection of the type of crude palm oil as raw material based on free fatty acid content, selection of biodiesel production process, availability of utilities in the palm oil mill, and calculation of estimated of investment and production costs.

\section{Methodology}

Since the focus of the study was to develop the concept of integration of biodiesel plant with the palm oil mill, therefore, the methodology was started with setting some assumptions based on available data \& experience (Anonym, 2013). Three scenarios for development strategy and study (David, 2002) were set for comparison of the study, namely: (i) scenario 1 biodiesel plant using CPO as raw material and not integrated with palm oil mill; (ii) scenario 2 - biodiesel plant using CPO as raw material and integrated with palm oil mill; and scenario 3 : biodiesel plant using offgrade CPO as raw material and integrated with palm oil mill. The assumptions according to the corresponding scenarios were shown in Table 1.

Table 1

Assumptions made for the comparison of study (Anonym, 2013)

\begin{tabular}{|c|l|l|l|l|}
\hline No & Assumptions & Scenario 1 & Scenario 2 & Scenario 3 \\
\hline 1 & Raw material of oil & CP0 & CP0 & 0ff-grade CP0 from POME \\
\hline 2 & Cost of oil (raw material), IDR/kg & 6,500 & 6,000 & 3,500 \\
\hline 3 & Location & Not integrated with palm oil mill & Integrated with palm oil mill & Integrated with palm oil mill \\
\hline 4 & Heat source & Steam supplied from purchased boiler & Steam supplied from palm oil mill & Steam supplied from palm oil mill \\
\hline 5 & Electricity & Supplied from genset & Supplied from palm oil mill & Supplied from palm oil mill \\
\hline
\end{tabular}

\subsection{Raw Material}

Types of raw material used for biodiesel production in this study were: (i) crude palm oil (CPO) with the content of free fatty acid less than $5 \%$, and (ii) off-grade crude palm oil extracted from palm oil mill effluent (POME). The availability of off-grade CPO from POME depended on the palm oil mill capacity to process fresh fruit bunch (FFB) per day. The amount of the off-grade CPO recovered from the palm oil mill with capacity of 30, 45 dan 60 tons FFB per day were estimated to be
1.5, 2.5 and 3 tons per day, respectively. The off-grade crude palm oil contained free fatty acid ranging from $40-60 \%$. The biodiesel plant capacity and, hence, the consumption of oil raw material depended on the demand of petro diesel fuel to be substituted with biodiesel fuel. The diesel fuel consumption in palm oil mill with capacity of 60 tons of fresh fruit bunches usually reached at the average of $600-1,000 \mathrm{~kg}$ diesel fuel per day for start-up the palm oil mill and for 
transportation (Anonym, 2013). In this case, therefore, the biodiesel plant capacity was set to be 1 tons per day.

Oil raw material was reacted with methanol (min 95\%) with presence of a catalyst: an acid catalyst (sulfuric acid) for esterification reaction and a base catalyst (potassium or sodium hydroxide) for transesterification reaction. Hot water was used to wash and separate biodiesel from methanol and glycerol remaining in the biodiesel product.

\subsection{Biodiesel Production Technology}

Available technologies for biodiesel production were by esterification followed by transesterification method or direct transesterification method, depending on the content of free fatty acid in the oil raw material. Oil raw material with relatively low content of free fatty acid (lower than 5\%),such as RBDPO, RBDPS and CPO sold in the market, was processed with the direct transesterification reaction by addition of methanol mixed with a base catalyst, and then followed by separation and purification processes. But, oil raw material with higher content of free fatty acid (higher than 5\%), such as PFAD and off-grade crude palm oil from POME, was processed with the esterification reaction followed by the transesterification reaction. Biodiesel produced was then separated from glycerol and excess methanol by washing process, and purified by vacuum evaporation and filtration (Paryanto et al, 2007).

\subsection{Estimation of Investment and Production Costs}

Investment cost was estimated by calculating all cost items related to the project for building a biodiesel plant with production capacity of 10 tons/day. Cost items calculated covered costs of : feasibility study; engineering; procurement, fabrication and installation of all equipmentsand vessels as well as equipment supporting structures, electricals, instrumentations and piping; commissioning and training; and overhead costs

Production cost was estimated by calculation of a fixed cost (costs of labour, maintenance, depreciation) and a variable cost (costs of oil raw material, methanol, catalysts, water, other chemicals and utilities).

\section{Result and Discussion}

\subsection{Comparison of Raw Material Specification and Handling}

Specification of oil raw material used for biodiesel production in this study was : (i) CPO with the content of free fatty acid less than $5 \% \mathrm{w} / \mathrm{w}$ and (ii) off-grade crude palm oil, extracted from palm oil mill effluent (POME), containing free fatty acid ranging from 40-60\% $\mathrm{w} / \mathrm{w}$ and its water and solid impurities from $6-9 \% \mathrm{w} / \mathrm{w}$. At $40^{\circ} \mathrm{C}, \mathrm{CPO}$ was in the form of liquid, whereas off-grade $\mathrm{CPO}$ in the form of solid (Paryanto et al, 2007).

Handling activities of raw material using CPO and off-grade CPO were compared in Table 2. It was shown in Table 2 that handling off-grade CPO as raw material needed extra equipment accessories for treatment such as heater, insulation and a degumming tank with filters.

\subsection{Comparison of Production Process}

The biodiesel production process was described in Figure 1. The off-grade CPO (scenario 1) was firstly extracted and treated from POME to remove solid impurities. Before it was reacted by esterification, it was treated again to remove gum (degumming). The treated oil was then mixed with methanol and corresponding catalyst, and undergone two steps reactions (esterification and transesterification) followed by separation and purification processes to get biodiesel product. Methanol was recovered using a distillation column and recycled and mixed with fresh methanol.

If CPO was used as raw material (scenarios 2 and 3 ), then it could directly undergo transesterification reaction followed by separation and purification processes. The biodiesel production process using CPO as raw material had shorter and simpler processing steps than that using off-grade CPO.

\subsection{Comparison of Estimated Investment and Production Costs}

Based on the assumption and calculation, the investment cost of 1 TPD capacity of biodiesel plant was shown in Table 3. It was illustrated from this table that the estimated investment cost of biodiesel plant integrated with palm oil mill (scenarios 2 and 3 ) had the lower values compared to the one not integrated with palm oil mill (scenario 1). This was mainly due to the additional investment on utilities such as a steam boiler and water supply source. The reduction of the investment cost, if biodiesel plant was integrated with palm oil mill, was $25 \%$ (scenario 2) and 15\% (scenario 
3). Although off-grade CPO had lower price, however, the cost of treatment and reaction step caused additional equipment, and hence, additional investment cost in scenario 3, compared to scenario 2 .

As far as the production cost was concerned, the biodiesel plant using off-grade CPO from POME had the lowest production cost because of lowest price of oil raw material as shown in Table 4. It was also noted that the cost of oil raw material contributed most of the production cost (more than $80 \%$ ). By integration of biodiesel plant with palm oil mill, the production costs for both scenarios 2 and 3 (Table 4) can be reduced by $12 \%$ and $30 \%$, respectively, compared to scenario 1 .

Table 2

Raw Material Handling Activities using CPO and Off-Grade CPO

\begin{tabular}{|c|l|l|l|}
\hline No & Handling Activities & CPO & Off-Grade CPO \\
\hline 1 & Oil transportation tank & without installed heater & with installed heater \\
\hline 2 & Unloading & $\begin{array}{l}\text { with heated piping system to } \\
\text { transfer/ unloading }\end{array}$ & $\begin{array}{l}\text { with heated piping system to } \\
\text { transfer/ unloading }\end{array}$ \\
\hline 3 & Storage & $\begin{array}{l}\text { Storage tanks installed with } \\
\text { heater and piping is heated } \\
\text { for transfer }\end{array}$ & $\begin{array}{l}\text { Storage tanks installed with } \\
\text { heater and piping is heated } \\
\text { for transfer }\end{array}$ \\
\hline 4 & Pretreatment & Usually not required & $\begin{array}{l}\text { Required to remove solid and } \\
\text { water impurities as well as } \\
\text { gum content }\end{array}$ \\
\hline
\end{tabular}

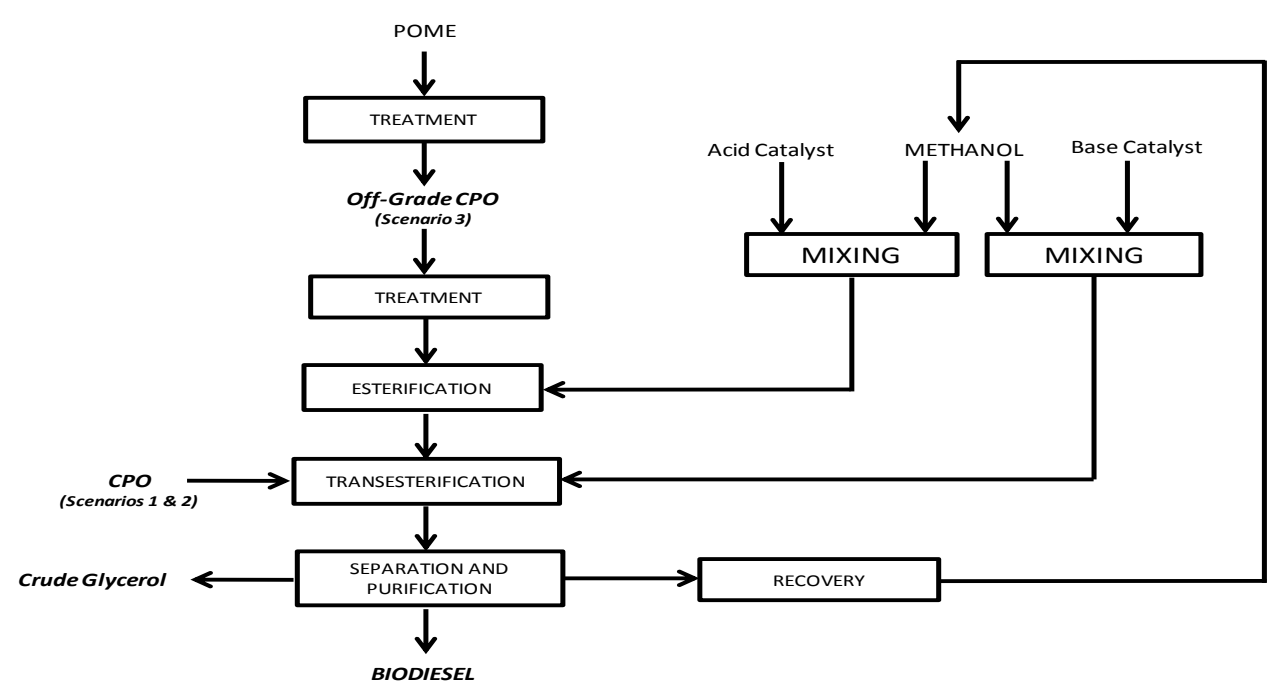

Fig.1 Biodiesel Production Process (Scenarios 1, 2 and 3) 
Table 3

Estimated Investment Cost of Biodiesel Plant 1 TPD

\begin{tabular}{|c|c|c|c|c|}
\hline \multirow[b]{2}{*}{ No } & \multirow[b]{2}{*}{ Item } & \multicolumn{3}{|c|}{ Estimated Investment Cost of 1 TPD Biodiesel Plant, IDR } \\
\hline & & $\begin{array}{c}\text { Scenario 1 } \\
\text { (Not integrated with } \\
\text { palm oil mill \& CPO as } \\
\text { raw material) }\end{array}$ & $\begin{array}{c}\text { Scenario } 2 \\
\text { (Integrated with palm oil } \\
\text { mill \& CPO as raw } \\
\text { material) }\end{array}$ & $\begin{array}{c}\text { Scenario } 3 \\
\text { (Integrated with palm oil } \\
\text { mill \& off-grade CPO from } \\
\text { POME as raw material) }\end{array}$ \\
\hline 1 & Building \& civil works & $400,000,000$ & $400,000,000$ & $400,000,000$ \\
\hline 2 & Equipment (including accessories \& structures) & $650,000,000$ & $650,000,000$ & $745,000,000$ \\
\hline $\mathbf{3}$ & Storage tanks (raw material \& product) & $160,000,000$ & $70,000,000$ & $90,000,000$ \\
\hline 4 & Pumps \& motors & $195,000,000$ & $130,000,000$ & $170,000,000$ \\
\hline 5 & Utilities (steam, electricity/genset, water) & $415,000,000$ & $100,000,000$ & $100,000,000$ \\
\hline 6 & Electrical \& Instrumentation & $165,000,000$ & $100,000,000$ & $125,000,000$ \\
\hline 7 & Piping (including support \& insulation) & $335,000,000$ & $185,000,000$ & $270,000,000$ \\
\hline $\mathbf{8}$ & Feasibility study (internal) \& engineering & $250,000,000$ & $250,000,000$ & $250,000,000$ \\
\hline 9 & Commissioning \& training & $100,000,000$ & $100,000,000$ & $110,000,000$ \\
\hline 10 & Overhead & $125,000,000$ & $125,000,000$ & $125,000,000$ \\
\hline & Total & $2,795,000,000$ & $2,110,000,000$ & $2,385,000,000$ \\
\hline & Estimated Reduction of Investment Cost & - & $25 \%$ & $\mathbf{1 5 \%}$ \\
\hline
\end{tabular}

Table 4

Estimated Production Cost of Biodiesel Plant 1 TPD

\begin{tabular}{|c|c|c|c|c|}
\hline \multirow[b]{2}{*}{ No } & \multirow[b]{2}{*}{ Item } & \multicolumn{3}{|c|}{ Estimated Production Cost of 1 TPD Biodiesel Plant, IDR/kg } \\
\hline & & $\begin{array}{c}\text { Scenario 1 } \\
\text { (Not integrated with } \\
\text { palm oil mill) }\end{array}$ & $\begin{array}{c}\text { Scenario 2 } \\
\text { (Integrated with palm } \\
\text { oil mill) }\end{array}$ & $\begin{array}{c}\text { Scenario } 3 \\
\text { (Integrated with palm } \\
\text { oil mill) }\end{array}$ \\
\hline A & Fixed Cost & & & \\
\hline $\mathbf{1}$ & Plant overhead (costs of labour, maintenance, etc) & 655 & 655 & 785 \\
\hline 2 & Depreciation & 950 & 685 & 800 \\
\hline B & Variable Cost & & & \\
\hline \multirow[t]{3}{*}{$\mathbf{1}$} & Raw material & & & \\
\hline & - CPO/CPO off-grade & 6,500 & 6,000 & 3,750 \\
\hline & -Methanol, catalysts, etc & 856 & 856 & 1,150 \\
\hline \multirow[t]{3}{*}{2} & Utilities & 485 & 95 & 130 \\
\hline & Total & 9,446 & $\mathbf{8 , 2 9 1}$ & 6,615 \\
\hline & Estimated Reduction of Production Cost & - & $\mathbf{1 2 \%}$ & $30 \times 6$ \\
\hline
\end{tabular}




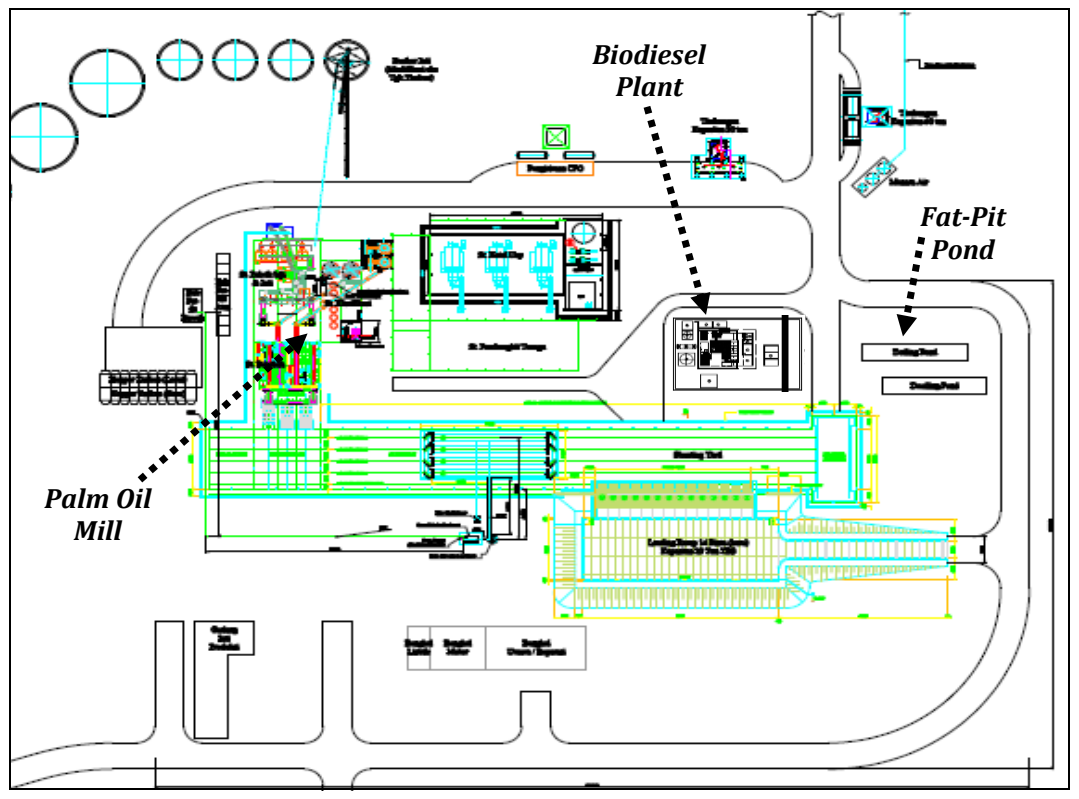

Fig.2 A Biodiesel Plant Integrated with a Palm Oil Mill

\section{Conclusion}

Biodiesel plant integrated to the palm oil mill (Figure 2) was one of the strategies to produce biodiesel fuel with lower investment and production costs, and the biodiesel product could be used for substituting diesel fuel for internal use in the oil palm industry. Development of biodiesel plant with appropriate capacity will ensure the supply of biodiesel fuel for diesel fuel substitution in oil palm industry.

\section{References}

Ahmad, A.L., Chan, C.Y., AbdShukor, S.R., Mashitah, M.D., (2008) Recovery of oil and carotenes from POME, Chemical Engineering Journal, 141, 383-386.
Anonym (2013), Progress Report of DIPA Project of the Engineering Design Study for Integration of Biodiesel Plant into a Palm Oil Mill, BRDST-BPPT.

David, F.R (2002), Strategic Management: Concept and Cases, $10^{\text {th }}$ ed., Prentice Hall International.

Government of Indonesia (2006), President Regulation No.5/2006 about National Energy Policy.

Investor Daily (2012), 2013 Produksi CPO Indonesia Naik 10 Persen, Investor Daily Indonesia, 27 December 2012

Paryanto, I., Kismanto, A., Amri, K., Solikhah, M.D. (2013), Some Aspects for Sustainable Biodiesel Production, International Journal on Advanced Science Engineering Information Technology, 3(3), 49-53.

Paryanto, I, Solikhah, M.D,Kismanto, A., Rahmadi, A. Wirawan, S.S. (2007),Perbandingan Proses Produksi Biodiesel denganBahan Baku CPO Standardan CPO Parit, Prosiding GelarTeknologi Industri Kelapa Sawit, BPPT, 382-390. 